\title{
Acute Toxicity of Brucea javanica Merril Leaves Extract on Mice
}

\author{
Marissa Angelina ${ }^{1 *}$, Indah D. Dewijanti ${ }^{1}$, Banjarnahor S.D.S. ${ }^{1}$, Megawati $^{1}$,Tri Yuliani $^{1}$ \\ ${ }^{1}$ Research Centre for Chemistry, Indonesian Institute of Sciences
}

\begin{abstract}
The objective of the study was to evaluate the oral acute toxicity of Brucea javanica Merril extract on both Male and Female DDY-Mice. Brucea javanica leaves function as a cytotoxic, anti-diarrhoea, etc. Brucea javanica leaves extract was administered orally for the first 24 hours at various dose levels $(562.5$ $\mathrm{mg} / \mathrm{kg}$ bw (body weight), $1125 \mathrm{mg} / \mathrm{kg} \mathrm{bw}, 2250 \mathrm{mg} / \mathrm{kg} \mathrm{bw}$, and $4500 \mathrm{mg} / \mathrm{kg} \mathrm{bw}$ ) to determine the toxicity effects. The treatment groups were compared to the normal control. Vital organs (liver, heart, lymph, lungs, etc) and body weight were analyzed to study the toxicity. $\mathrm{LD}_{50}$ was determined using Reed and Munich formula. Vital organs average weight showed no difference between the control group and the treatment groups from the lowest dose until the highest dose. In addition, the body weight data showed no difference between the control group and the treatment groups. $\mathrm{LD}_{50}$ for Brucea javanica extract using Reed and Munich formula was $1003.65 \mathrm{mg} / \mathrm{kg} \mathrm{bw}$. The result of the study showed that the extract was categorized as "slightly toxic".
\end{abstract}

Keywords: Acute toxicity, Brucea javanica Merril, DDY-Mice, $L D_{50}$

\section{BACKGROUND}

The tree plant Brucea javanica Merril is a member of the Simaroubaceae family, which is known for its medicinal value to some Asian countries. This plant is an evergreen shrub distributed from Southeast Asia to Northern Australia. The fruit of this plant has been used in the traditional medicine of Indonesia and China $[1,2]$. In Indonesia, the fruit is known as "Buah Makassar" and has demonstrated anti-malaria, anti-pyretic, and homeostatic effects. In China, the fruit is known as "Ya-Tan-Tze" and is used to treat malaria and amoebic dysentery and as an insecticide [3] and anti-cancer [4]. The isolation of the indole alkaloid canthin-6-one from Brucea $s p$. has been reported by some workers [5,3]. The compound and its hydroxylated and methoxylated derivatives have demonstrated cytotoxic effects and marked activities against malaria, leukemia, carcinoma, keratinocytes of guinea-pig ear, and bacteria [4].

Previous investigations on the chemical constituents of B. javanica have focused mainly on the fruit and seeds and have found its major constituent, namely quassinoids, which are

\footnotetext{
* Corresponding address:

Marrisa Angelina

Research Centre for Chemistry,

Indonesian Institute of Sciences

Kompleks Puspiptek, Serpong-Indonesia 15412

Email: marissa_angelina@yaho.com
}

the bitter principle of many species in the family of Simaroubaceae. Quassinoids from B. javanica have been documented with a wide spectrum of biological effects, such as having potential antibabesial, anti-HIV, antimalarial, antitubercular, antitumor, cancer chemopreventive, and cytotoxic activities. Research on other parts of B. javanica is limited, but apotirucallanetriterpenoids and b-carboline alkaloids occur as major consti-tuents besides the quassinoids.

Considering both the ethnobotanical and pharmacological applications of the plant, the aim of this study was to investigate the possible acute toxic effects of the aerial parts of the plant in mice using vital organs weight parameter.

\section{MATERIAL AND METHODS}

\section{Preparation of Extracts}

Dried Brucea javanica leaves were macerated with Et-OH before evaporated.

\section{Experimental Animals}

Male and female DDY mice weighing 25-30 g and eight-week old were obtained from our laboratory. All of them were maintained in a controlled environment condition of temperature $\left(24+1^{\circ} \mathrm{C}\right)$ in alternative 12 highlight/dark cycles and were fed on standard diets with a regular supply of water and libitum. 


\section{Acute Toxicity Study and $L D_{50}$ Determination}

The animals were divided into five groups each consisting of ten male and female. Treatment groups received the extract orally in a single dose with varied dose $(562.5 \mathrm{mg} / \mathrm{kg}$ bw (body weight), $1125 \mathrm{mg} / \mathrm{kg}$ bw, $2250 \mathrm{mg} / \mathrm{kg} \mathrm{bw}$, $4500 \mathrm{mg} / \mathrm{kg} \mathrm{bw}$ ), while the control group received a vehicle. The animals were observed for 14 days after the administration. The animals that died within 14-day period were subjected to necropsy. All of the mice were weighted daily and sacrificed on day 15 after the administration, and then the vital organs including heart, liver, lungs, kidneys, spleen, adrenal, gastric, and sex organs were grossly examined. The analysis of $\mathrm{LD}_{50}$ was evaluated using the Reed and Munich Method [6].

\section{Statistical Analysis}

Data obtained were expressed as a mean and standard deviation. Statistical significance was determined using one-way analysis of variance (Anova) and least significance difference (LSD) test. $\mathrm{P}$ values less than 0.05 were considered significant.

\section{RESULT AND DISCUSSION}

The oral administration of Brucea javanica leaves extract in doses ranging from $562.5 \mathrm{mg} / \mathrm{kg}$ bw to $4500 \mathrm{mg} / \mathrm{kg}$ bw did not produce significant changes in behavior, breathing, cutaneus effect, sensory nervous system responses, and gastrointestinal effects in male and female mice [data not shown]. These effects were observed during the experimental period [2 hours after the oral route]. During the 14 days after the oral administration, there were 26 deaths in both male and female groups and at the highest dose $(4500 \mathrm{mg} / \mathrm{kg} \mathrm{bw})$, there was $26 \%$ mortality. The alteration of body weight gain and organ weights of the treatment groups compared to the control group would reflect the toxicity of the substance [7]. Significant difference in organ weights between the treatment and control group may occur in the absence of any morphological changes [8]. However, there were no significance difference in organ weight showed with the result of the statistic analysis in which $\mathrm{p} \geq 0.05$. Vital organ body weights both in male and female mice were recorded as shown in figure 1 and figure 2. Neither body weight nor vital organs weight of the treated mice was significantly changed relative to the control group. Gross examination of the vital organs revealed no pathological abnormality relative to the control group based on the macroscopic observation (data not shown). Size, tumors, olours, and textures are parameters that observed in macroscopic observation.

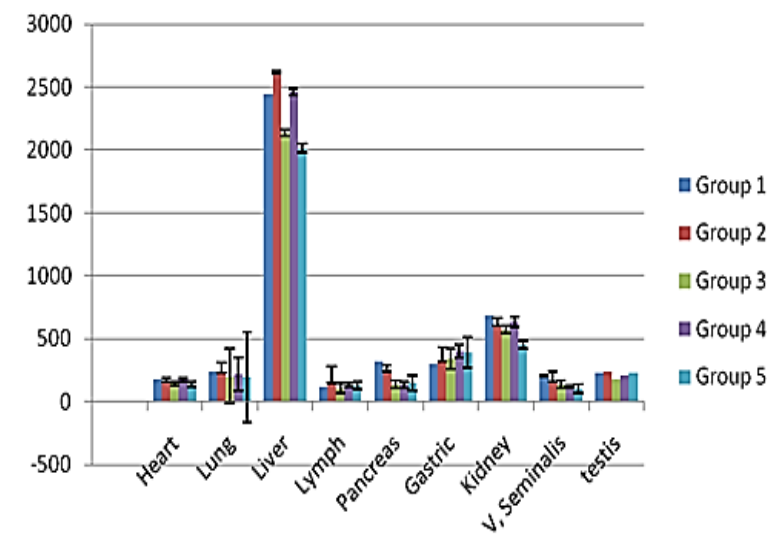

Figure 1. Organ Weight of Male Mice in the Acute Toxicity Study of the Brucea javanica Leaves Extract. Group 1: Normal control, Group 2 : Treated group with dose $562.5 \mathrm{mg} / \mathrm{kg}$ bw, Group 3 : Treated group with dose $1125 \mathrm{mg} / \mathrm{kg}$ bw, Group 4 : Treated group with does 2250 $\mathrm{mg} / \mathrm{kg}$ bw, Group 5 : Treated group with dose $4500 \mathrm{mg} / \mathrm{kg}$ bw.

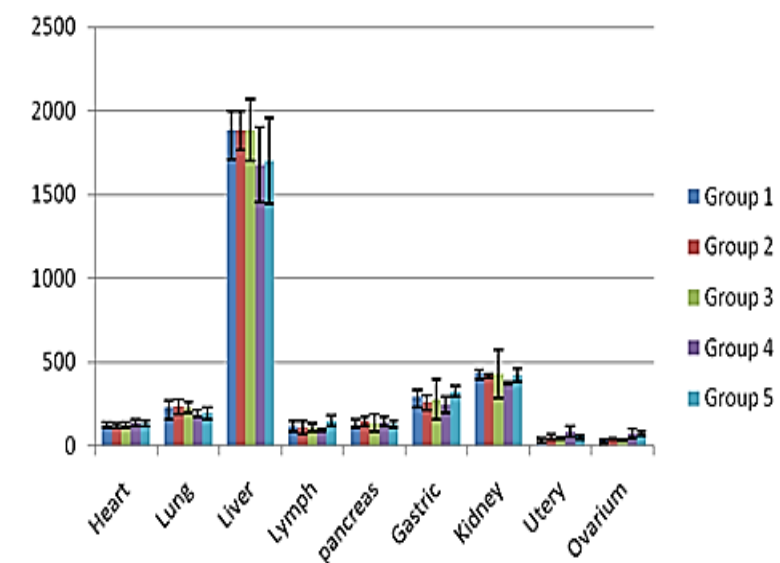

Figure 2. Organ Weight of Female Mice in The Acute Toxicity Study of The Brucea javanica Leaves Extract. Group 1: Normal control, Group 2 : Treated group with dose $562.5 \mathrm{mg} / \mathrm{kg}$ bw, Group 3: Treated group with dose $1125 \mathrm{mg} / \mathrm{kg}$ bw, Group 4 : Treated group with does 2250 $\mathrm{mg} / \mathrm{kg}$ bw, Group 5 : Treated group with dose $4500 \mathrm{mg} / \mathrm{kg}$ bw.

The median lethal dose $\left(\mathrm{LD}_{50}\right)$ obtained from the Reed Munich method [6] was $1003.65 \mathrm{mg} / \mathrm{kg}$ bw for both male and female mice. The result showed that Brucea javanica leaves extract is sligthly toxic for oral administration. Slightly toxic means that temporary minor injury will result from contact with, or absorption of, a 
small to moderate amount by a healthy adult. Larger quantities of exposure could, however, cause greater damage. Mice and humans have similarity, which is both of them are mammals. If the extract is slightly toxic in mice, hopefully so is in human. The others antimalarial drugs which are slightly toxic are Amodiaquine (LD 50550 $\mathrm{mg} / \mathrm{kg}$ in mouse, oral) [9] and Quinacrine ( $\mathrm{LD}_{50}$ $1000 \mathrm{mg} / \mathrm{kg}$ in mouse, oral) [10].

\section{CONCLUSION}

A single oral dose of $562.5,1125,2250$, and $4500 \mathrm{mg} / \mathrm{kg}$ bw of Brucea javanica leaves extract are unable to induce acute toxic effects although there were 26 deaths occurred during the experimental period. LD $_{50}$ calculated using the Reed Munich Method is $1003.65 \mathrm{mg} / \mathrm{kg}$ bw for both male and female mice. The data on the acute toxicity study indicates that Brucea javanica is mild toxic for oral administration. In conclusion, Brucea javanica Merril extract with $\mathrm{LD}_{50} 1003.65 \mathrm{mg} / \mathrm{kg}$ (mouse, oral) used in this study is possible to be developed as a future drug, because the damage to the body caused by this extract is minor and not permanent, considering the dose.

\section{ACKNOWLEDGMENTS}

The authors thank to the DIPA LIPI.

\section{REFERENCES}

1. Hasbi M (1979) Pharmacognostic study of Brucea amarissima Merr. from Gowa, South Sulawesi, Indonesia, "Isolation and identification quassinoid compound by thin layer chromatography“. Research Report. Hasanuddin University, Faculty of Natural Sciences.

2. Alam G, Soegihardjo CJ, Sudarsono (1994) Detection of indole alkaloid in the callus culture of Brucea javanica (L) Merr. Proceedings the 8th Symposium on Medicinal Plants Research. 24-25 November 1994. Bogor. pp:452-456.

3. Liu KCS, Lin YS, Roberts MF and Phillipson JD (1990) Canthin-6-one alkaloids from cell suspension cultures of Brucea javanica. Phytochemistry. 29(1):141-14

4. Anderson LA, Harris A and Phillipson JD (1983) Production of cytotoxic canthin-6-one alkaloids by Ailanthus altissima. Plant Cell Cultures. J. Nat. Products. 46(3): 374-378.

5. Harris P, Scragg AH, Smart NJ and Stafford A (1985) Secondary product formation by cell suspension culture. In: Plant Cell Culture - a Practical Approach. Dixon RA (ed.). IRL Press. Washington DC. pp:127-167
6. Reed LJ and Muench M (1958) A Simple Method of Estimating Fifty Percent End Product. Am. J. I. L. 27:495-497

7. Carol S A (1995) Acute, Subchronic, and Chronic Toxicology. In: Michael, J.D., ManfredAH. Eds. CRC Handbook of Toxicology. US. CRC Press Inc. pp:51-104

8. Bailey SA, Zidell RH and Perry RW (2004) Relationship between Organ Weight and Body/Brain Weight in the Rat: What Is The Best Analytical Endpoint?. Toxicol. Pathol., 32(4) : 448-466

9. Drug Bank, Open Data Drug \& Drug Target Database http://www.drugbank.ca /drugs/DB00613

10. Drug Bank, Open Data Drug \& Drug Target Database /drugs/DB01103] http://www.drugbank.ca 